\title{
Environmental Impacts Analysis of Mining on the Surrounding Communities: A Case Study of Rutongo Mines Ltd in Rulindo District, Northern Province of Rwanda
}

\author{
Hyacinthe Kazindu, Christophe Mupenzi, Abias Maniragaba \\ Department of Environmental Information Systems, Faculty of Environmental Studies, University of Lay Adventists of Kigali, Kigali, \\ Rwanda
}

\author{
Email address: \\ Kazindubh@gmail.com (H. Kazindu),mupenzic@gmail.com (C. Mupenzi)
}

\section{To cite this article:}

Hyacinthe Kazindu, Christophe Mupenzi, Abias Maniragaba. Environmental Impacts Analysis of Mining on the Surrounding Communities: A Case Study of Rutongo Mines Ltd in Rulindo District, Northern Province of Rwanda. Journal of Energy and Natural Resources. Vol. 9, No. 2, 2020, pp. 56-69. doi: 10.11648/j.jenr.20200902.12

Received: March 10, 2020; Accepted: April 1, 2020; Published: May 14, 2020

\begin{abstract}
Mineral exploitation contributes significantly to economic growth and development in most world economies. However, from the detection of minerals to their exploitation, there are a number of procedures and methods applied to attain the main objective of economic growth through the exploitation of natural resources. This study examined some known methods of mineral extraction and their impact on environmental degradation and community resources as well. To achieve this objective, data was collected in the mining zones and its surrounding community. Four (4) communities (Masoro, Ntarabana, Cyinzuzi and Murambi) within Rutongo Mines zone were covered; a total of 100 respondents were contacted for relevant information through questionnaire and interviews. The collected data was analyzed using tools like Microsoft word, Microsoft Excel and Arc GIS. The results from data analysis showed that mining activities depleted environmental resources like soil, water, and vegetation; spatial analysis revealed that 509.12 ha were converted from crop land to bare land between year 2010 and 2018 while 193.12 ha of forest land was converted also to bare land; this land cover change impacted the community resources causing shortage and loss of many assets accessed by them. The finding highlighted remarkable relationship between poor methods in minerals exploitation and environmental degradation. In addition to this, illegal mining contributes to rivers pollution, air pollution and deforestation. Therefore, mitigation measures for environmental protection should be implemented this include soil erosion control measures like radical terraces, reforestation and anti-erosion ditches.
\end{abstract}

Keywords: Rutongo Mines Ltd, Minerals Extraction Methods, Environmental Impacts, Landover Change, Communities Resources

\section{Introduction}

Rapid economic development requires various activities to exploit natural resources. One of such activities is mining; an activity which involves excavation of the surface and subsurface for the purpose of exploiting and processing minerals, In North America, raw mineral production in 1998 was valued at approximately US\$ 70 billion. The industry employs approximately 1 million people. In Peru, the mining sector accounts for $50 \%$ of the country's annual export earnings [1].

In Ghana, the sector plays a vital role in the development of the economy. In 2000 , minerals accounted for $38.96 \%$ of total export earnings, followed by cocoa $(22.51 \%)$ and timber $(9.03 \%)$ [2].

The mining sector now contributes $41 \%$ to the country's foreign exchange and is the leading foreign exchange earner. Of the $\$ 612.9$ million in total mineral export income in 1997, gold, the most important mineral, accounted for $\$ 579.2$ million, or $94.5 \%$, while the remaining $5.4 \%$ came from diamonds, bauxite and manganese [3].

In Rwanda, Cassiterite (tin ore) had the largest production and export volume at about 3,874 tons valued at US $\$ 42.2 \mathrm{~m}$ in 2010. It is followed by coltan with 749 tons in 2010 valued at $\$ 18.48 \mathrm{~m}$ and tungsten ore with 843 tons in 2010 valued at 
\$7.1m. Recent statistics, however, show that mineral exports amounted about US\$ 346 million in 2018, down from US\$ 374 million in 2017 [4].

Rwanda also produces about $9 \%$ of the world's tantalum, used in electronics manufacturing. It possesses in addition variety of minerals such as good quality silica sands, kaolin, vermiculite, diatomite, clays, limestone, talcum and gypsum. The production listed above shows that mining is an important activity performed in Rwanda and pays an important role in economic growth and country development. The target of Rwanda is 'trading in minerals, including cassiterite, wolframite and niobium. There is a need to develop industrial minerals in order to meet the 'demand for construction materials especially tiles, slabs sculptures, paints, bricks and concrete aggregates [5].

There is no doubt that natural resources such as cassiterite, coltan, wolfram, and so many others can contribute significantly to economic development of many countries. The Government of Rwanda has placed much emphasis on the role and contribution of the mining sector to assist in the economic development of the country [6].

However, Mining activities carried out in the different countries affected environment and health of community surrounding the areas of exploitation. The health cost of mining operations sometimes outweighs the benefits gained. In view of this, despite these positive indicators, the role of the mining industry in the economic development of Ghana is a suspect. Despite the over U\$2 billion Foreign Direct Investment (FDI) in mineral exploration and mine development during the last decade indicating over $56 \%$ of total FDI flows to the country, the sector is yet to make any meaningful impact on the country's overall economy [7].

According to Rwanda audit report on environmental issue 2015, mining companies that excavated topsoil to access ore in Gasabo, Rulindo, Kayonza, Muhanga and Ngororero districts; "did not collect, store it and install traps as required by standards". The soil in these mine sites was in disarray state near the mining pits and surrounding areas [8]. According to Muhanga District Environmental reports 2014, the impact of mining on natural resources is a great concern. The report said that "there were cases where top soil from sites of Rwanda Rudniki and SOREMI sent in Nyabarongo River and marshland". This shows that the topsoil exposed to erosion when it rains flows down in the rivers near these mine sites and they become polluted and as consequences all people around these rivers suffer from the lack of clean water. Apart from being a burden to environment, the loss of original topsoil will be very expensive in future for the operators and local communities who will lack fertile soil for farming [9].

Hence like in other countries all over the world, in Rwanda particularly Rutongo Mines area in Rulindo District of Northern Province of Rwanda, these mining activities affect the environment both positively and negatively and it is in this regard that the present research is intended to investigate the environmental impacts of Mining activities and propose related mitigation measures and review particularly the issues that communities could face as consequence of mining once nothing is done to address the problem.

\section{Materials and Methods}

In this study, the data included background data on respondents, awareness, perception and effects of mining on the surrounding communities of the mining zone. Data about the impacts of mining in Rutongo mines areas on the environment were collected and analyzed. Moreover, data on interventional measures dealing with the environment as well as the safety health measures being put in place by the company and communities were collected and analyzed; finally, datasets of the study area were also collected from Rwanda Mining Board and online to analyze the impacts of mining on land cover using GIS and remote sensing software.

Land degradation due to mining activities was analyzed using land cover change mapping by using GIS and Remote Sensing methods and techniques. Land cover change detection were used with the goal to identify and quantify the amount of land that was converted from more productive land cover types (forest \& crop land) to unproductive land cover types (bare land). The results of this analysis were interpreted with an underlying assumption that mining is the principal factor that contributes to forest degradation and denudation in Rutongo; therefore, the transformation of land from forest or crop land to bare land is attributable to the mining activities in the area.

The land cover maps of Rutongo area were produced using Landsat images acquired in 2010 and 2018 respectively. In order to remove cloud cover in the images, the Google Earth image composition algorithm for Landsat image collections was used and the dates corresponding to the dry season in Rwanda (1st June - 31st August) were selected for the two reference years (2010 \& 2018).

\subsection{Satellite Image Classification}

After downloading the images, ESRI's ArcMap software was used to clip them to the outer boundary of Rutongo mines concessions using the 'Extract by Mask' tool. The clipped images were then projected to WGS84 UTM 36S projection (EPSG: 32736 ) to make them ready for image classification.

The selection of the image classifier was limited to what ArcMap offers and therefore the Maximum likelihood ${ }^{1}$ method was chosen. The land cover classes used in the classification were selected basing on our familiarity with the study area and '(1) Forest cover, (2) Crop land and (3) Bare land' were identified as the best land cover classes that align well with the objectives of our study.

Training samples were prepared drawing on our knowledge of and familiarity with the study area and basing on ESRI's base map that uses high resolution GeoEye satellite images (Figure 1).

These training samples were saved as a shape file and used to create signature files that were used during the actual image classification step.

1 Maximum Likelihood is a pixel-based classification method and it is useful in applications where the input images have coarse spatial resolutions as is the case for Landsat. 


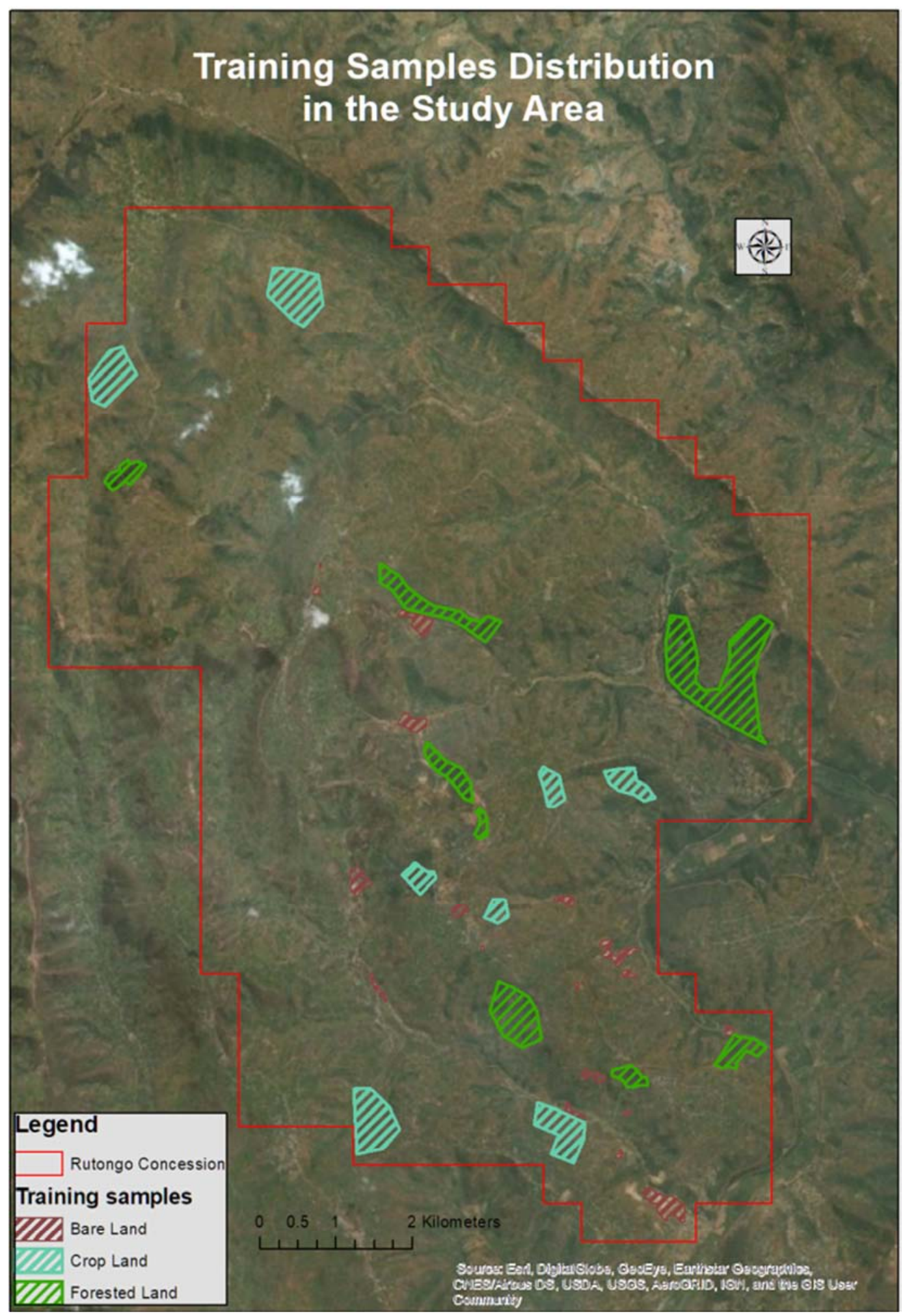

Figure 1. Distribution of Classification Training Samples in the Study Area.

After preparing the signature files for each image, the ArcMap's Maximum Likelihood classification tool was run twice using default parameters and the classified images for year 2010 and 2018 were produced and saved on disk

\subsection{Accuracy Assessment}

For each classified image produced, confidence rasters were also produced to help us examine the self-reported accuracy of the classifier (figure 2) below. 


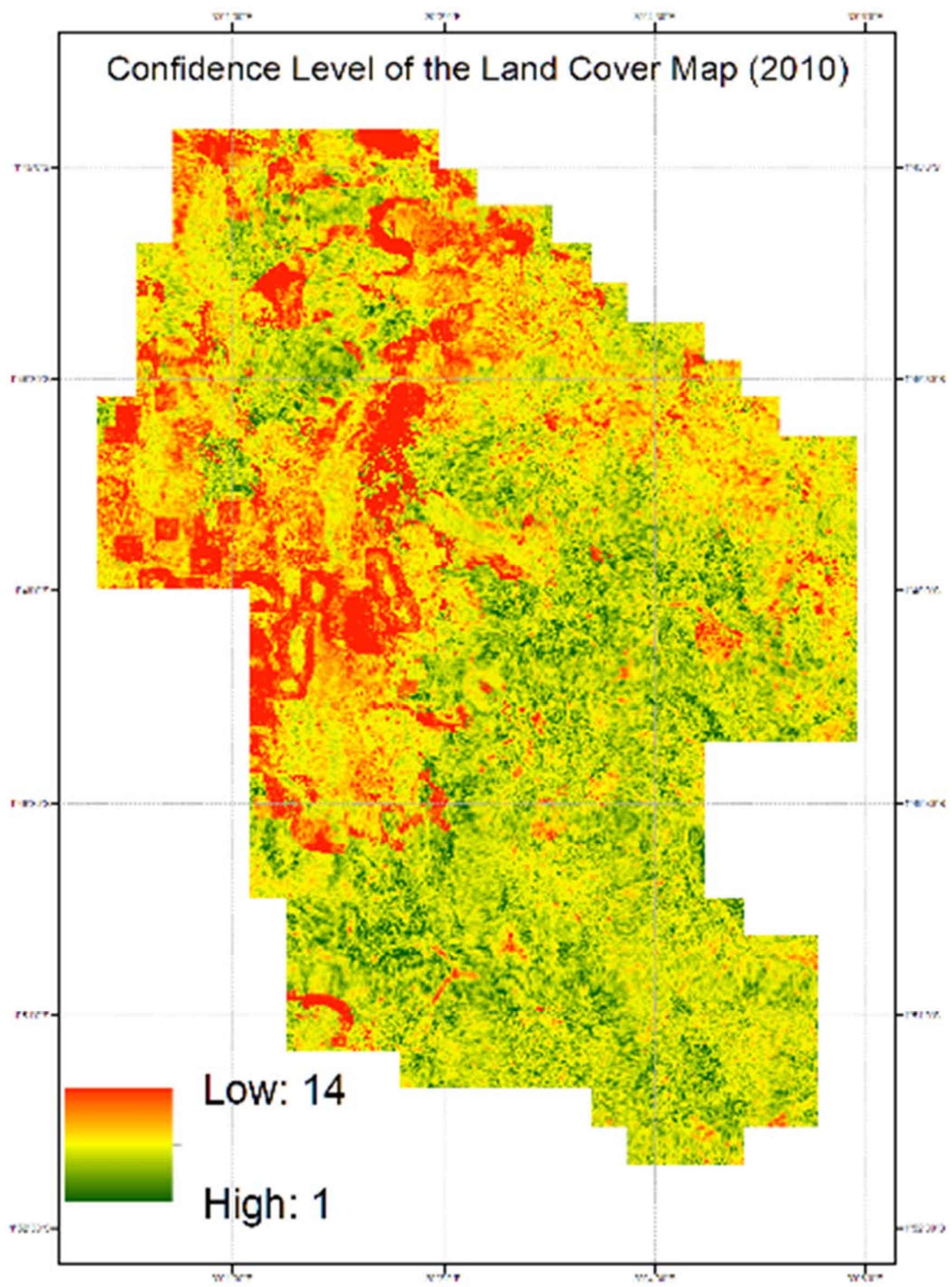




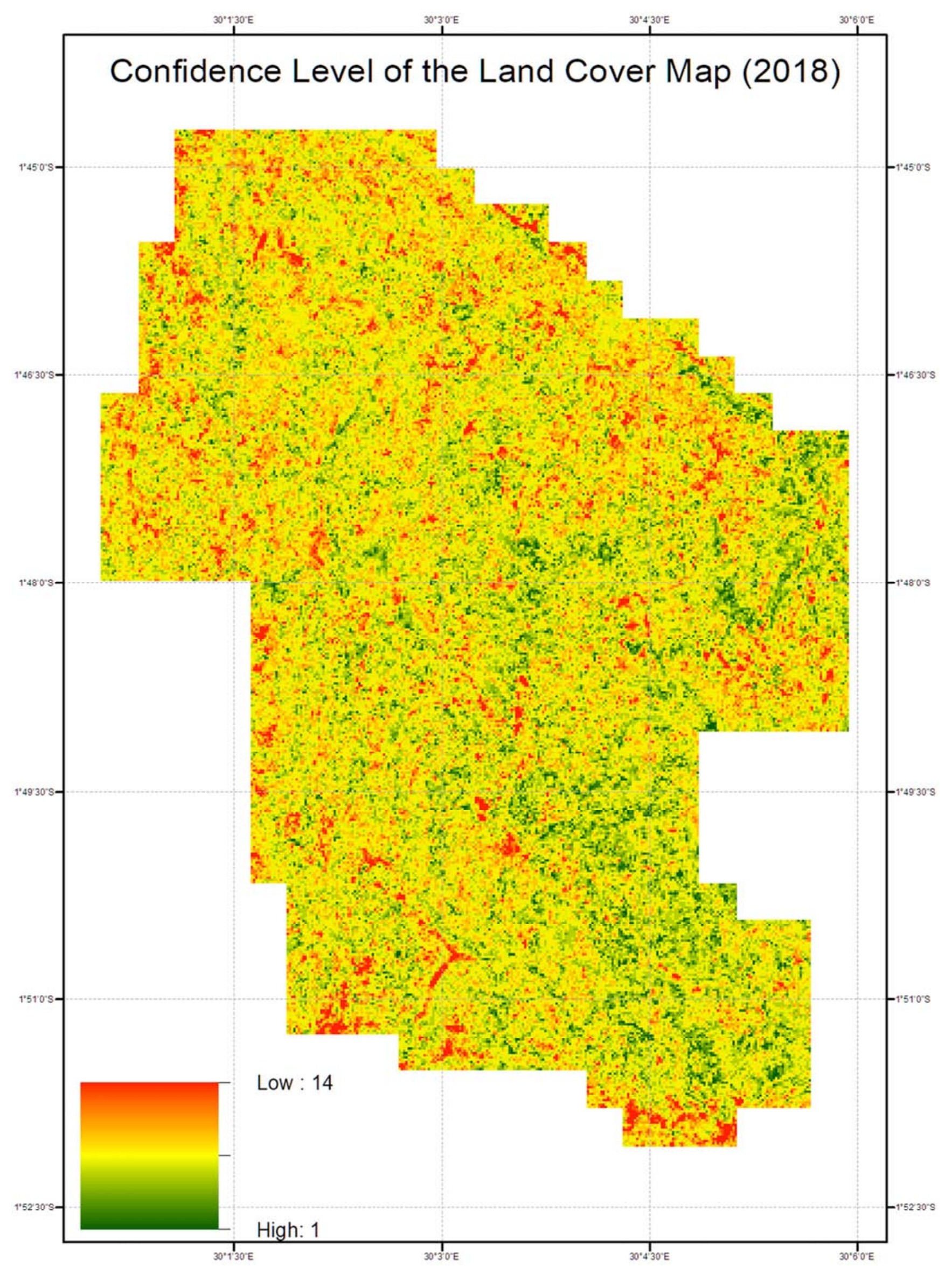

Figure 2. Confidence Rasters for the 2 Land Cover Maps Produced. 
These two maps depict the level of confidence that the classifier assigned the right class value to the corresponding pixels. The color green means that it is almost certain that the class assigned is the right one while the color red means that there is a lot of ambiguity.

As it can be seen from these confidence rasters, the landcover map for year 2018 is much more accurate. This is due to Landsat 8 sensor (OLI-TIRS) being much more advanced than the ETM+ sensor carried onboard Landsat 7. It is believed that a higher confidence level could be achieved by increasing the number of training samples, but time constraints prevented us from testing this hypothesis.

A more in-depth accuracy assessment of the landcover maps was conducted by using ground truthing points that were distributed across the study area using a stratified random sampling technique. In total, 50 points were selected, and their true class values were determined through visual image interpretation using high resolution GeoEye satellite images.

From these ground truthing data, confusion matrices were produced for the two land cover maps and Kappa coefficients and other accuracy indices were calculated.

Table 1. Contingency table for the land cover map 2010.

\begin{tabular}{|c|c|c|c|c|c|}
\hline & \multicolumn{5}{|c|}{ Reference image (GeoEye) } \\
\hline & & Bare Land & Crop Land & Forested Land & Totals \\
\hline \multirow{4}{*}{ Classified image (2010) } & Bare Land & 7 & 4 & 0 & 11 \\
\hline & Crop Land & 2 & 12 & 6 & 20 \\
\hline & Forested Land & 5 & 2 & 13 & 19 \\
\hline & Totals & 14 & 18 & 18 & 50 \\
\hline
\end{tabular}

From the above table 1, the following accuracy metrics were considered:

Overall Accuracy: $(7+12+13) / 50=0.62$

This metric quantifies the level of agreement between the reference image and the classified image. However, its usefulness is hampered by the fact that the agreement can be derived from 'chance'. In that regard, a more useful index, the Kappa coefficient $(\mathrm{K})$, which alleviates this 'chance' factor, was used.

$$
\mathrm{K}=\left(\mathrm{P}_{0}-\mathrm{P}_{e}\right) /\left(1-\mathrm{P}_{e}\right)
$$

Where $\mathrm{P}_{0}$ is the overall accuracy, $\mathrm{P}_{e}$ is the probability that pixel values between the reference and the classified image agree by chance, and $\mathrm{N}$ is the total number of cases (ground truth points).

$\mathrm{P}_{e}$ Is calculated by adding the product of the omission and commission errors for each class and then dividing by the number of cases.

In our case: $\mathrm{P}_{e}=((14 * 11 / 50)+(18 * 20 / 50)+(18 * 19 / 50)) / 50$ $=0.34$

From the values above, the Kappa Coefficient for the landcover map of year 2010 is:

$\mathrm{K}=(0.62-0.34) /(1-0.34)=0.42$

For the landcover map of year 2018, the accuracy assessment metrics were as follows:

Table 2. Contingency Table for the Landcover Map of Year 2018.

\begin{tabular}{|c|c|c|c|c|c|}
\hline & Reference ima & & & & \\
\hline \multirow{5}{*}{$\begin{array}{l}\text { Classified image } \\
(2018)\end{array}$} & & Bare Land & Crop Land & Forested Land & Totals \\
\hline & Bare Land & 11 & 2 & 1 & 14 \\
\hline & Crop Land & 2 & 12 & 2 & 16 \\
\hline & Forested Land & 1 & 4 & 15 & 20 \\
\hline & Totals & 14 & 18 & 18 & 50 \\
\hline
\end{tabular}

Kappa Coefficient: 0.64

As it can be observed from the accuracy assessment metrics of the two maps, the map of year 2018 is relatively more accurate than the one of year 2010. In order to examine more closely how this is likely to affect the findings of our study, we investigated more the confusion matrix of this map to produce the following additional accuracy metrics:

Table 3. Additional Accuracy Metrics for Landcover 2010.

\begin{tabular}{lll}
\hline Commission error (Bare Land): & 0.36 & Omission Error (Bare Land): \\
Commission error (Crop Land): & 0.40 & Omission Error (Crop Land): \\
Commission error (Forest): & 0.37 & Omission Error (Forest): \\
\hline
\end{tabular}

From this examination, we found that the omission error (which is a measure of how well reference pixels of the ground cover type are classified) for the 'Bare Land' class is the worst $(50 \%)$. This is due to the fact that bare land training samples were too small compared to other classes. However, since the commission error (the probability that a pixel classified into a given category actually represents that category on the ground) for that class is acceptable, then the result of this classification is still usable.

\subsection{Situation and Physical Characteristics of the Study Area}

The concession of Rutongo Mines Ltd is situated in the 
central part of Rwanda, about $10 \mathrm{~km}$ North of Kigali in the District of Rulindo, Northen Province of Rwanda. Its exploration and exploitation started in the 1930s. It has a large scale mining license in a concession of Surface Area of 9,432ha, its mining operations cover five Sectors namely Masoro, Murambi, Ntarabana, Cyinzuzi of Rulindo Distict and one Sector of Jabana in Gasabo District. During the first decades, production mainly came from eluvia and alluvial workings, but progressively exploitation was oriented underground by selectively mining the quartz veins. Cumulative production from different deposits in the Rutongo area reached 30,000 tons of cassiterite between 1931 and 1982. Currently, the possibilities for (semi-) industrial mining are being evaluated again. Secondary deposits are considered to be exhausted, but mainly primary resources are estimated at 6,700 tons of certain resource, 10,700 tons of probable resource and 6,900 tons of possible resource [10].

\section{Results}

\subsection{Effects of Illegal Mining on Landuse and Landcover Change}

Two landcover maps for Rutongo mines' concession were produced for year 2010 and 2018 (figure 3). The two maps depict the land cover situation at these two periods of time using 3 broadly defined land cover classes: Bare Land, Crop Land, and Forested Land

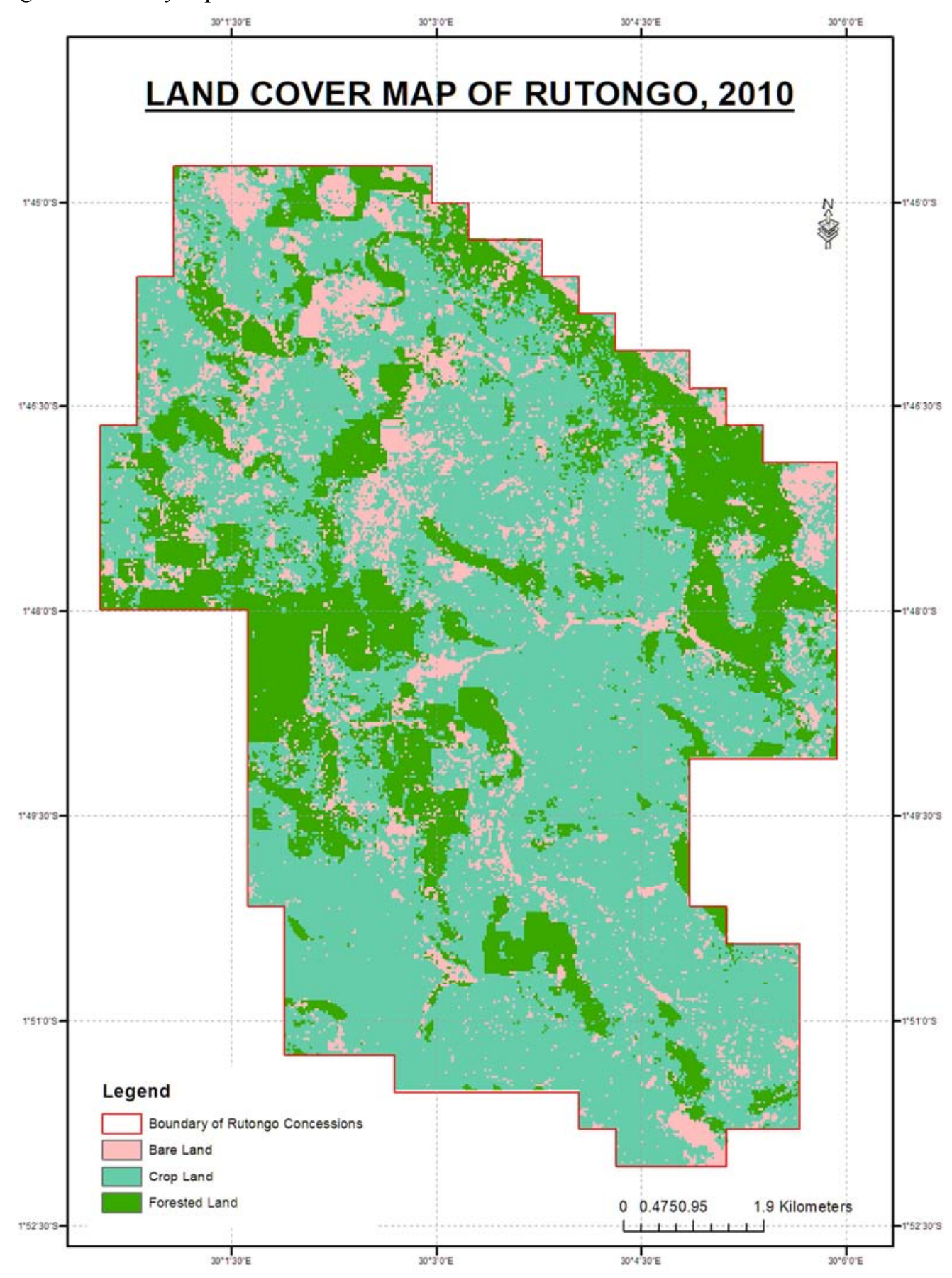




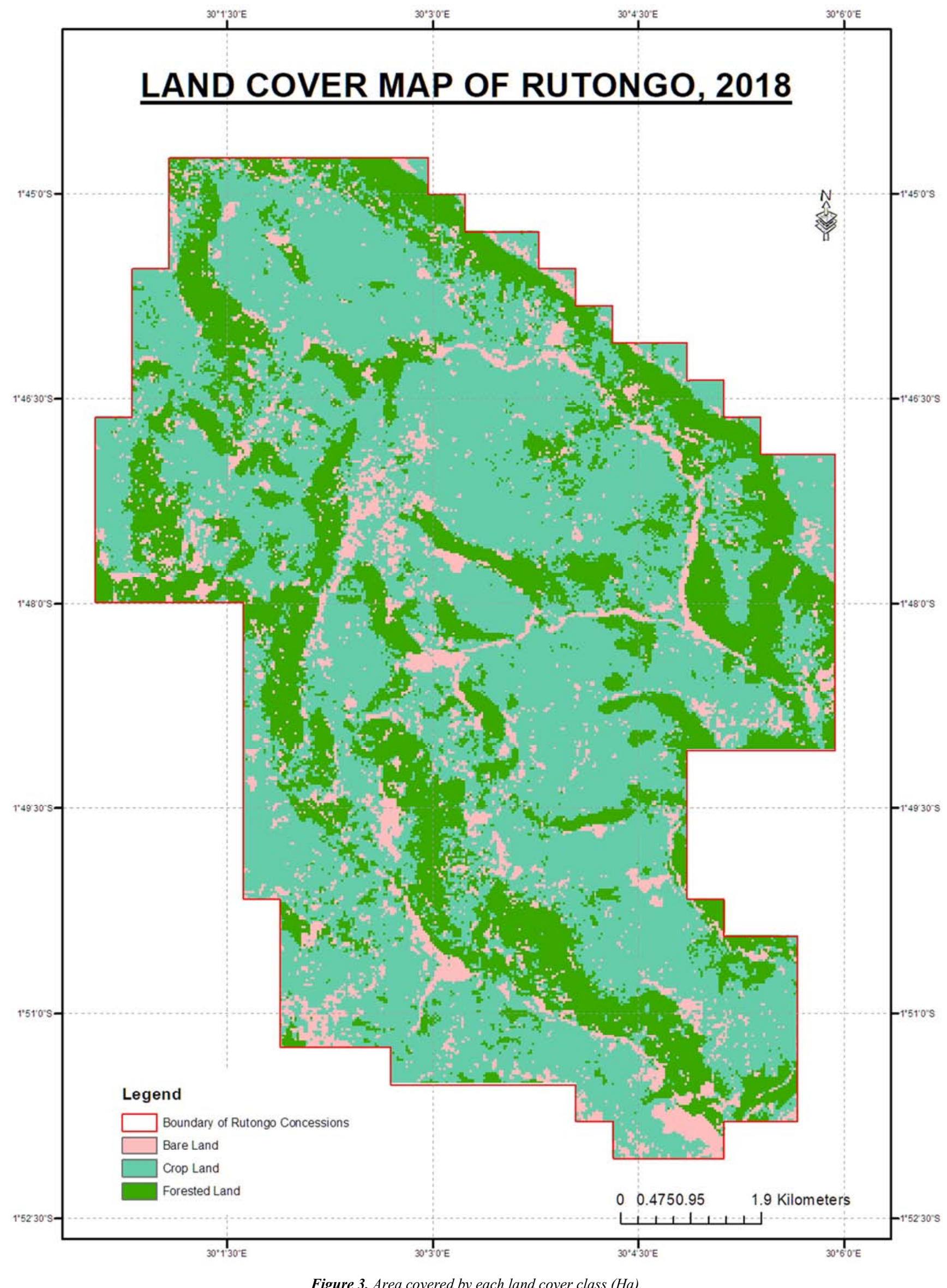


Using ArcMaps's 'Field Calculator' tool, the areas covered by each respective class on each map were calculated and plotted against each other to quantitatively study the change that might have occurred between these two dates.

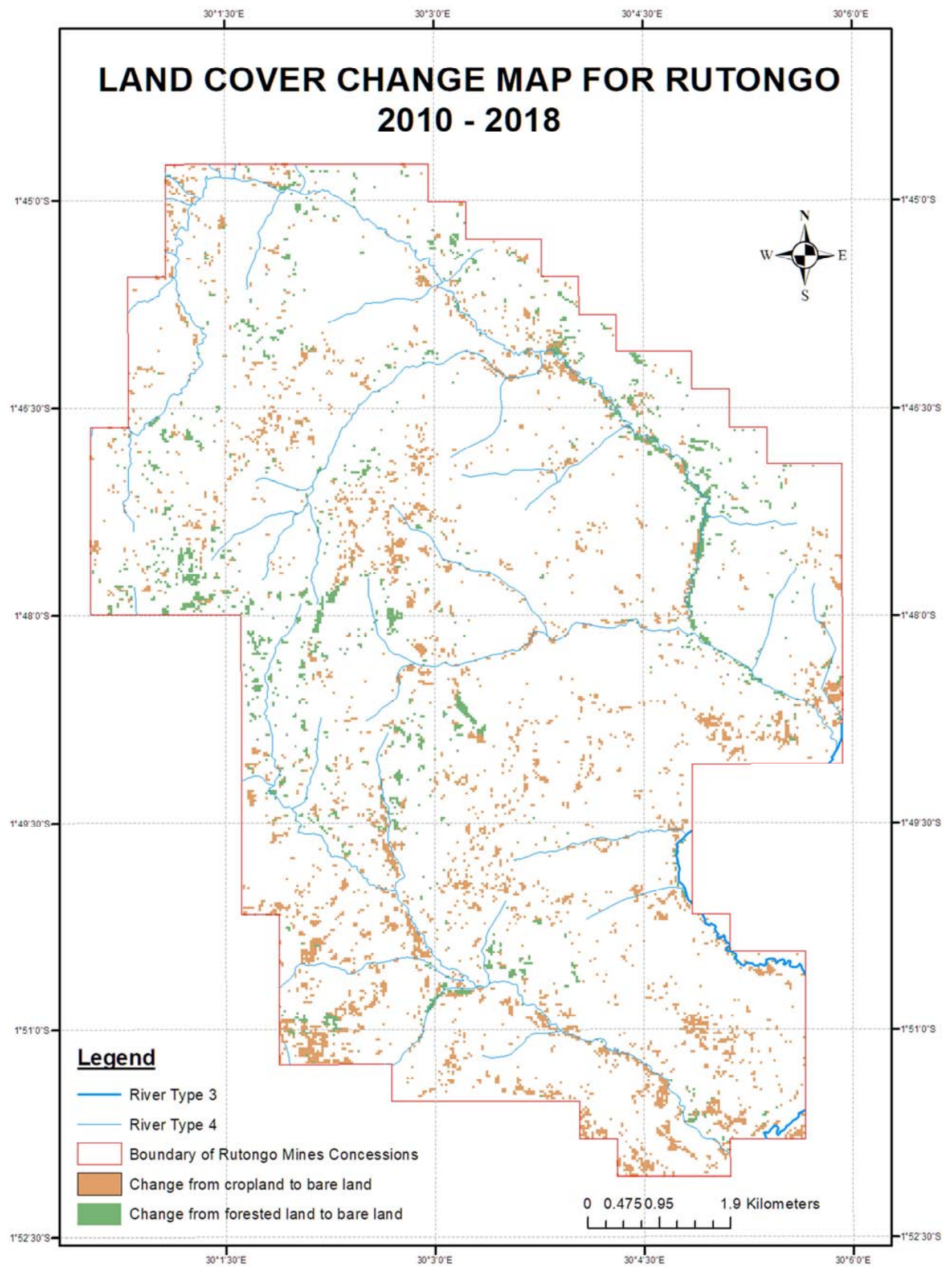

Figure 4. Map Depicting Change to Bare Land between 2010 and 2018. 
From this map, we calculated that $509.12 \mathrm{Ha}$ were converted from crop land to bare land between year 2010 and 2018 while $193.12 \mathrm{Ha}$ of forest land was converted. By overlaying the rivers layer onto this degraded land map, we find that much of the conversion from forested land to bare land occurred alongside major river streams in the study area namely Rusine, Mulindi, and Nyabugogo.

This clearly shows the linkage between this land degradation process and mining in Rutongo area since rivers constitute the hotspots of mining activities where artisanal mining operations to upgrade ores happen in the rivers. This was emphasized that the important environmental concern relates to land degradation associated with operating and abandoned mine sites and the multiple trenches found across the hillsides. This can impact on residents by reducing land available for farming, while the open and un-fenced shafts and pits scattered across the area pose a risk to livestock and humans [11].

\subsection{Land Cover Change Impacts on Community Resources}

\subsubsection{Lack of Clean Water}

According to respondents, the land cover change has impacts on water resource as follows:

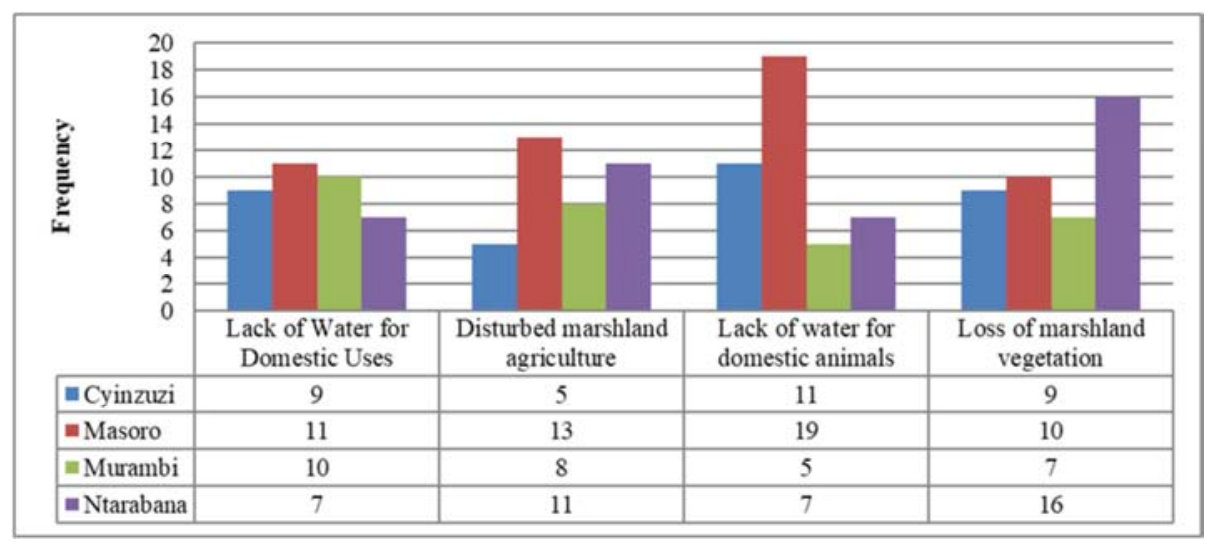

Figure 5. The impacts of land cover change on water resource.

Regarding to the lack of clean water, the respondents generally did not state this as a serious problem in the area as it was expected, although there are increased rivers pollution. In a sample of 100 persons involved in this research, only low number of them (37\% respondents) agreed that they have issues of clean water. This is due to abundance of facilities in clean water provided by the government in this area. However, 20\% respondents in Masoro and Cyinzuzi sectors agreed that they still have shortage of water for their domestic animals especially during the dry season. They said that this was due to pollution of rivers they use to feed their domestic animals. It is prohibited to dump, dispose of and store any substance in a place where it may cause or facilitate water pollution on the national territory and to use natural resources in a degrading and illegal manner [12].

\subsubsection{Forest Destruction Impact on Community Resource}

Respondents view point on deforestation as mining impacts on land cover.

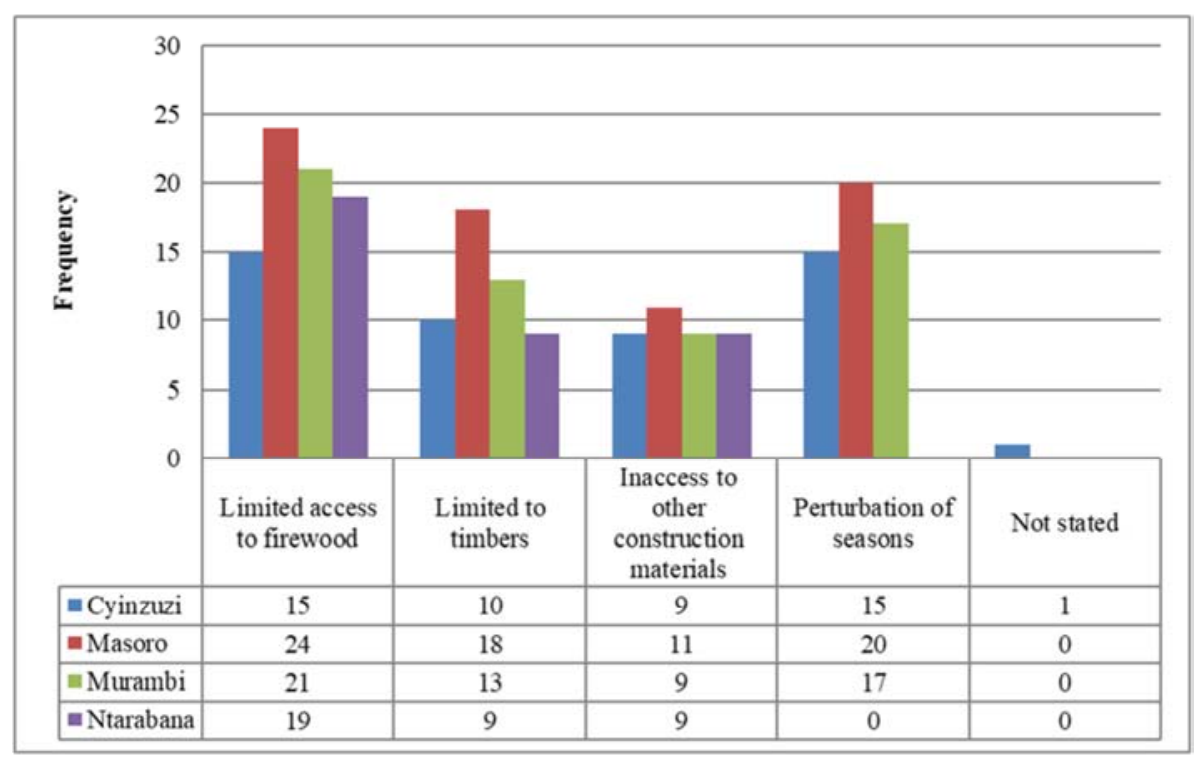

Figure 6. Forests destruction impact on community resources. 
The results of the present study also showed some resources like forest destroyed by miners in their minerals extraction. According to $79 \%$ of respondents from Cyinzuzi, Masoro, Murambi and Ntarabana participated in this research agreed that there is a shortage of domestic energy (charcoal and firewood) due to destruction of forest. This is a serious problem for people who live in rural area since the majorities depend on forest as main source of domestic energy [13]. The perturbation of seasons also constitutes another impact associated to deforestation in the area as mentioned by the statistics in the table above. $52 \%$ of the respondents said that there is frequent delay of rain season causing the dry of farmer's crops and shade off of their leaves. All the impacts discussed above are due to extraction of minerals in natural resources including forest. However it is prohibited to replace forests (individual, district, cooperative and state) of any size with other activities/projects unless it is approved by the Minister who has forest management in his attributions (Ministerial Instructions No 01024/MINIFOM/2010 of 28/12/2010 published in official Gazette No special 30/12/2010 article 11).

\subsubsection{Land Degradation and Soil Erosion Impact on Community Resources}

According to respondents, the landcover change has impacts on soil resource as follows:

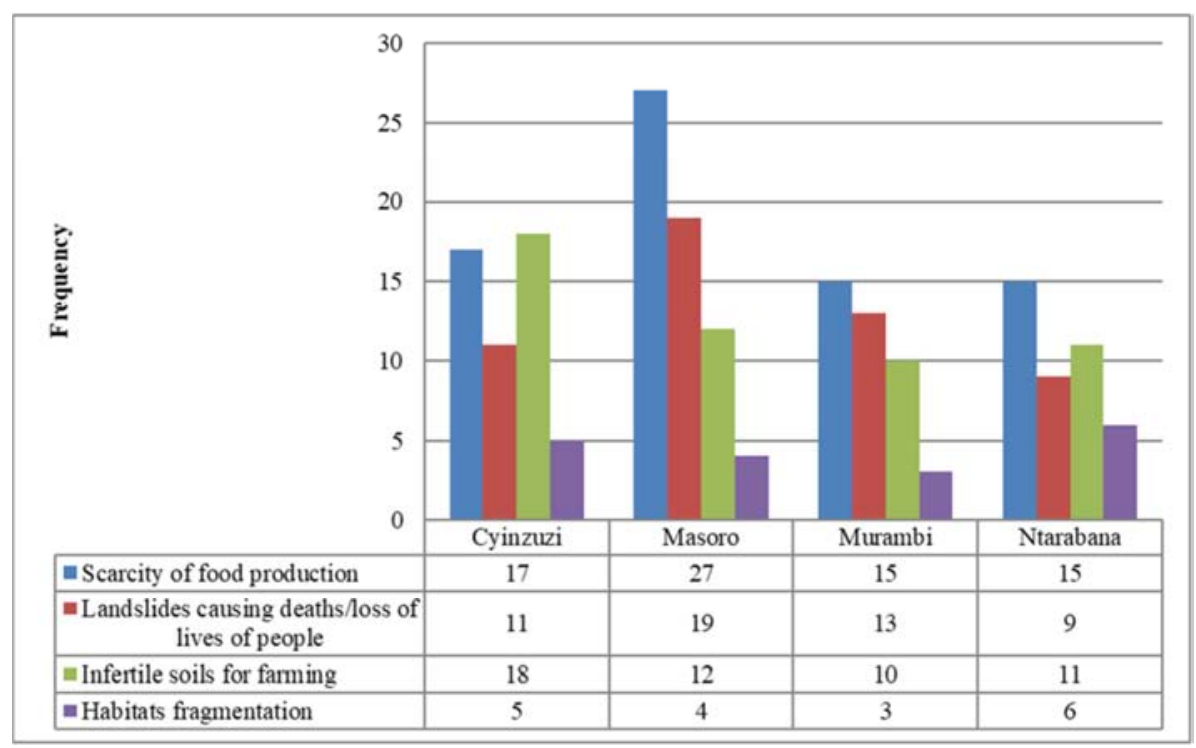

Figure 7. Impact of land degradation and soil erosion on community resources.

The impacts of environment destruction and land cover change on the community were demonstrated by respondents in the present study. According to $30 \%$ respondents of Masoro sector, the domestic food production is low compared to the needed of the entire area, due to the impact of land degradation as outcome of landcover change, they said that the production of Beans, Irish potatoes, Wheat, Passion Fruit, Coffee and Tea diminished remarkably. Respondents attributed this to the mining activities, as several farmlands have either been reserved for mining activities or degraded. $17 \%$ respondents out of $25 \%$ in Ntarabana confirmed that Land degradation has resulted from the removal of the top soils, trees and vegetation with heavy machines for mineral deposits. This has deprived the land of its nutrients and rendered it infertile for agricultural purposes. Consequently, few farmlands are available for farming activities. $20 \%$ respondents of Cyinzuzi are of the point view that the land cover change caused the fragmentation of habitat and no fertile soil for farming. Even of the lands available, some have been contaminated with chemicals from mining activities. The typical example is Rusine river which tends to be non-cultivable due to intensified siltation. In addition, tailings dam cover considerable portions of lands in communities such Gasambya and mahaza. Hence, farmers do not have access to such lands for farming activities. Effects of this situation on food production within the the consession area are very remarkable.

\subsubsection{Blasting of Dynamites Impacts on the Community}

Another major effect associated with underground mining is noise and vibrations emanating from blasting with dynamites. The ground vibrations and air blast produced by blasting are often felt by residents surrounding the mines. According to 18 respondents out of 25 in Cyinzuzi and 26 out of 30 respondents in Murambi Sector involved in the present study, mining blasting contribute to the loss of many resources including the cracking of their house and other public assets like school rooms. In addition to this, they said that they lose much money to repair their houses. This was also confirmed by the observation done during data collection in current study.

This land cover change results are in agreement with those of land degradation which represents a serious problem at a mine and is principally associated with the surface mining and disposal of tailings or waste rock. The land degradation starts after removal of the vegetation cover. However, the 
water colour can reveal physical, chemical and bacteriological conditions [14].

In drinking water, green can indicate copper leaching from plumbing and wastewater; this can also represent algae growth. Blue can also indicate copper, or might be caused by siphoning of industrial cleaners in the tank of commodes, commonly known as back flowing whereas in mining areas can come from refining and processing activities. Reds can be signs of rust from iron materials or airborne bacteria from water bodies, etc. Black water can indicate growth of sulfur reducing bacteria inside a hot water tank set to low a temperature [15].

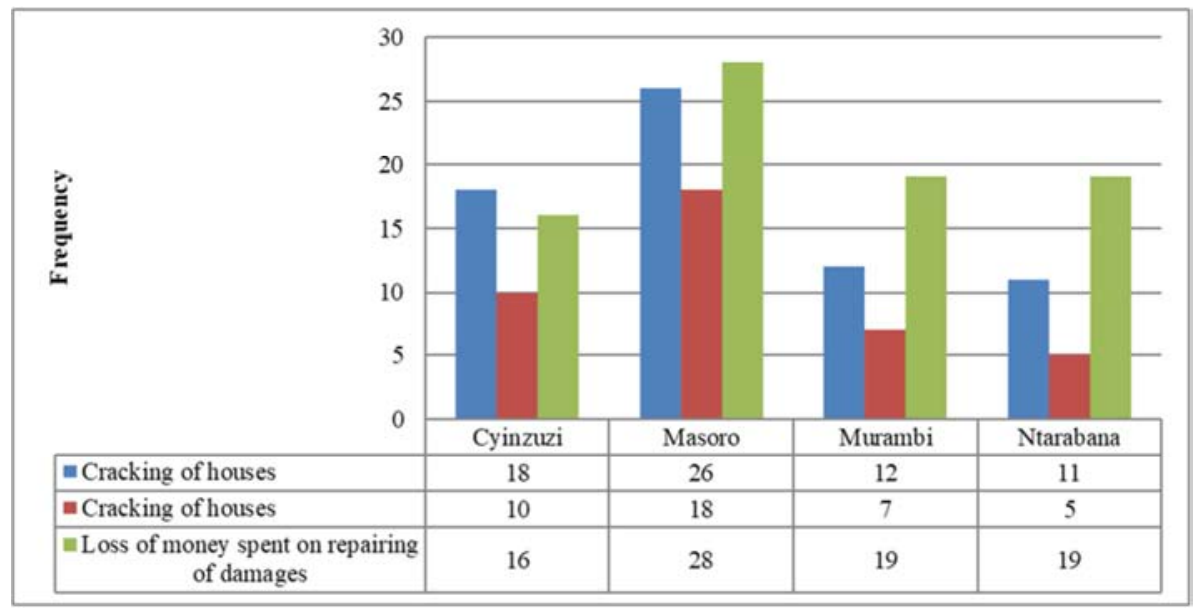

Figure 8. The impact of blasting of dynamites on community resources.

In addition, It stated that the results of mining activities range from formation of ridges, depressions, pits and subsidence on the surface as well as underground cavities affecting the stability of the ground [16].

The biosphere is adversely affected by mining mainly by pollution and by degradation of land and vegetation resulting in loss in biodiversity. Mining can also have impact on local microclimate [17].

Consequently, the removal of the top soils, trees and vegetation with heavy machines deprives the land of its nutrients and renders the land infertile for agricultural purposes [18].

\subsection{Facilities Provided to Surrounding Communities}

\subsubsection{Schools and water facilities}

Table 4. The Schools and water tanks constructed in Rutongo Mine Concession.

\begin{tabular}{lll}
\hline Location/Sector & School Rooms Constructed & $\begin{array}{l}\text { Water tanks } \\
\text { constructed }\end{array}$ \\
\hline Cyinzuzi & Groupe Scholaire de Remera & 4 \\
& Groupe Scholaire de Gihinga & 4 \\
Masoro & Group Scholaire de Masoro & 4 \\
& E. P Murehe & 2 \\
\multirow{2}{*}{ Murambi } & Ecole Primaire de Shengampuli & 2 \\
& Groupe Scholaire de Mugambazi & 4 \\
& Ecole Primaire de Ntyaba & 6 \\
Ntarabana & BUBANGU High School & 3 \\
\hline
\end{tabular}

By researcher observation, some facilities however have been put in place by the Rulindo District. This is the mechanism proposed by the government for mining revenues sharing to support the communities living near the mining sites this programme is known as Corporate Social Responsibilities in mines (CSR). These facilities are very important because they help people to deal with environmental impacts emanating from overexploitation of natural resources. In addition to this there is a school named Rutongo Mining School constructed in 2016, and it is considered as emanating from Rutongo Mining Zone. Other facilities includes "health insurance care paid for vulnerable people surrounding the mining sites and distribution of cows, Gira Inka munyarwanda"and so many others effort to improve community welfare.

\subsubsection{Rutongo Settlement Development}

This initiative is financed by Rwanda Housing Authority and is considered as one way of promoting this area that has undergone environmental degradation due to overexploitation of natural resources. Integrated Development Projects (IDP Model villages) in Rutongo mine concession have the following pillars:

1. Land Productivity - to increase agricultural and livestock productivity;

2. Post Harvest Processing and Marketing - to assure food security and promote trade of agriculture products in internal and export sales

3. Resettlement - to voluntarily settle citizens for efficient service delivery and land consolidation

4. Rehabilitating ecosystem - to ensure optimal utilization and sustainable management of natural resource base

5. Infrastructure development: to improve access to affordable electricity and transport infrastructure as support to economic transformation and access to other forms of energy (peat, biogas, solar) for improved welfare and environmental protection. 
Table 5. The IDP Village Models offered to Rutongo community.

\begin{tabular}{lll}
\hline DISTRICT & Site & Component available in this IDP Model village \\
\hline & & Constructed of 10 houses (4 in 1) \\
& Constructed of Cowshed (for 20 cows) \\
RULINDO & Constructed of a nursery school at Cyinzuzi Sector \\
& Construction of access road in Murambi Sector \\
& Construction of Dining hall at Masoro high school \\
\hline
\end{tabular}

\section{Conclusion}

The present research was conducted in order to evaluate the Environmental Impacts Analysis of Mining on the Surrounding Communities; After quantifying collected data and analyzing them in statistical form, spatially, and after referring to interviews and observation done as well as to the opinions of respondents involved in the present research, the result of the present study showed that with exception to "lack of clean water" where a limited number of respondents $(37 \%)$ agreed that they do not have any problem associated to clean water, the majority $(73 \%)$ said that they have difficulties associated with the lack of domestic energy as mining impact on deforestation, land degradation (unproductive soil/bare land), blasting (noise, cracking of houses etc..). Illegal mining and poor methods used in minerals extraction contribute to environment destruction and land cover change. The degradation of soil caused the loss of vegetation cover, over-exploitation of natural resources and inappropriate minerals extraction methods, poor management of top soil and lack of anti-erosive measures,

Finally, in as much as we acknowledge the economic benefits of mining activities in Rwanda, there is the need also to recognize the environmental hazards especially water and soil contamination that come with it in order to find ways of dealing with them.

\section{Recommendations}

Rwanda Mines, Petroleum and Gas Board (RMB) as an institution responsible for Mining governance in Rwanda, should request and enforce mining operators to design facilities that will capture waste water from mining and consider the recycling and suspend all created channels heading to rivers and restore disrupted rivers and land. Environmental Impact assessment must be emphasized by RMB to all mining companies before any activity regarding minerals extraction taking place in natural reserves. Rutongo Mines Ltd should prepare and implement soil erosion control measures in all its mine sites in order to avoid surface run off and prevent siltation and pollution of near rivers but also regular mines inspection should be emphasized, encourage use of modern methods of mining, equipments and technology. Finally, Ministry of Local government through Local Authorities and in collaboration with security organs should also actively enforce in day to day monitoring and controlling any illegal mining that could hinder the environment in the area. Apart from RMB, all other institutions in relation with natural resources and environment in Rwanda like Ministry of Environment, Rwanda Environmental Management Authority (REMA), Rwanda Water and Forestry Authority (RWFA), Rwanda Development Board (RDB) and Rwanda Land Management and Use Authority (RLMUA) should play their roles exhaustively to protect and manage the natural resources and environment not only in Rutongo Mines Areas but also all over the country.

\section{Acknowledgements}

We are highly indebted to all academic staffs of the University of Lay Adventist of Kigali (UNILAK) especially in the department of Environmental Information Systems for their skills provided and assistance towards the completion and success of this paper; we are also gratefully to Rwanda Mines Petroleum and Gas Board (RMB), Mining company and community of Rutongo for their detailed information for the data collection and warm communications during our field survey.

\section{References}

[1] Mbendi (2004), World Mining Overview, http://www.mbendi.co.za/indy/ming/p0005.htm

[2] Institute of Statistical, Social, and Economic Research (ISSER) (2001), The State of the Ghanaian Economy in 2001. University of Ghana, Legon.

[3] Institute of Statistical, Social, and Economic Research (ISSER) (1998), The State of the Ghanaian Economy in 1998. University of Ghana, Legon June (p 67-68).

[4] Banqué Nationale du Rwanda (BNR). 2017-2018. Annual Report: Towards a price based monetary policy framework. BNR: Kigali.

[5] RSEO (2009), Industry and Mining, Chapter III, page 3.

[6] Rwanda, R. O. 2017. National Strategy for Transformation 1, 2017-2024. MINECOFIN: Kigali.

[7] Office of Auditor General of State Finances. (2015). Perfomance Audit Report of Environmental Management of Mining Activities. Period of 1 January 2012 to 31 January 2015. Office of the Auditor General of State Finances (OAG): Kigali.

[8] Awudi, B. K. (2002), The Role of Foreign Direct Investment (FDI) in the Mining Sector of Ghana and the Environment. A Paper Presented at the Conference on Foreign Direct Investment and the Environment $7-8$ February 2002, OECD, Paris - France by George B. K. Awudi, Friends of the Earth Ghana, Accra, www.oecd.org/dataoecd/44/12/1819492.pdf 
[9] Schwarz R., Gerth A., Morgenstern S. and Hebner A., (2009). Strategies for managing environmental problems and water treatment in mining. International Mine Water Conference. ISBN: 978-0-9802623-5-3. Pretoria, South Africa.

[10] AGASSIZ, J. F., 1954. Géologie et pegmatites stannifères de la région Mumba-Numbi, Kivu (Congo belge). Comité National du Kivu, nouvelle série, 7.

[11] Barreto, M. L, Schein, P., Hinton, J. \& Hruschka, F. 2018. Economic Contributions of Artisanal and Small-Scale Mining in Rwanda: Tin, Tantalum and Tungsten. EARF Project 'Understanding the Economic Contribution of Small-Scale Mining in East Africa' covering Kenya, Rwanda, and Uganda. January.

[12] Rwanda, R. O. Law on Mining and Quarry Operations. Official Gazette n 33 of 13/08/2018.

[13] NISR, 2012. Fourth population and housing census, Kigali. Rwanda.

[14] Doran, J. W., A. J. Jones, M. A. Arshad, and J. E. Gilley. (1999). Determinants of soil quality and health. In: R. Lal (ed) "Soil Quality and Soil Erosion," CRC/SWCS, Boca Raton, FL: $17-36$.

[15] Braun, Charles L., and Smirnov, Sergei N. (1993). Why water is blue. Journal of Chemical Education, 70 (8): 612-614, Bibcode: 1993JChEd. 70. 612B.

[16] Jenny A. Nilsson and J. Randhem, (2008). Environmental Impacts and Health Aspects in the Mining Industry: A Comparative Study of the Mining and Extraction of Uranium, Copper and Gold. Master of Science Thesis in the Master Degree Programme Industrial Ecology. Department of Energy and Environment. Division of Environmental Systems Analysis. Chalmers University of Technology. Göteborg, Sweden, 2008. Report No. 2008: 20.

[17] Ashton, P. J., D. Love, H. Mahachi, P. H. G. M. Dirks (2001). An Overview of the Impact of Mining and Mineral Processing Operations on Water Resources and Water Quality in the Zambezi, Limpopo and Olifants Catchments in Southern Africa. Contract Report to the Mining, Minerals and Sustainable Development (SOUTHERN AFRICA) Project, by CSIR Environmentek, Pretoria, South Africa and Geology Department, University of Zimbabwe, Harare, Zimbabwe. Report No. ENV-P-C 2001-042. Pp 28.

[18] Yeboah Y. J., (2008). Environmental and health impact of mining on surrounding communities: A case study of Anglogold Ashanti in Obuasi. Department of Geography and Rural Development. Kwame Nkrumah University of Science and Technology. Ghana. August 2008. Pp. 22-24. 